\title{
Modeling boron adsorption on five soils before and after removal of organic matter
}

\author{
Patricia dos Santos ${ }^{1}$, Sabine Goldberg ${ }^{2}$, Antonio Carlos Saraiva da Costa ${ }^{1 *(0)}$
}

\author{
'Universidade Estadual de Maringá - Depto. de Agronomia, \\ Av. Colombo, 5790 - 87020-900 - Maringá, PR - Brasil. \\ 2USDA/ARS, George E. Brown, Jr., Salinity Laboratory, 450 \\ W. Big Springs Road - 92507 - Riverside - CA - USA. \\ *Corresponding author <acscosta@uem.br>
}

Edited by: Tiago Osório Ferreira

Received January 29, 2018

Accepted January 10, 2019

\begin{abstract}
Boron-B concentrations that cause deficiency and those that cause toxicity appear to be very similar, compared to other nutrients, which can complicate successful management of this element in soils. In this study, $B$ adsorption onto two Oxisols from Brazil (Rhodic Eutroperox and Anionic Acroperox), two Alfisols (Natric Palexeralf and Aridic Paleustalf) and an Entisol (Xeric Torrifluvent) from the United States of America were evaluated. The samples were treated with sodium hypochlorite in order to remove soil organic matter. Both treated and untreated samples were used to determine $B$ adsorption isotherms using different $B$ concentrations ( 0 $\left.4.630 \mathrm{mmol} \mathrm{L}^{-1}\right)$ and $\mathrm{NaNO}_{3}(0.05 \mathrm{M})$ as background electrolyte solution at $\mathrm{pH}$ 7. Boron adsorption envelopes were also measured using $0.463 \mathrm{mmol} \mathrm{L}^{-1} \mathrm{~B}$ at three ionic strengths $(0.05$, 0.1 and $1 \mathrm{M}$ ) and $\mathrm{NaNO}_{3}$ as background electrolyte solutions at different $\mathrm{pH}$ values (3-12). The cation exchange capacity, specific surface area, free Al and Fe oxides, organic and inorganic carbon content, mineralogy and particle size distribution of the soils were also determined. The Langmuir isotherm and the constant capacitance model were fit to the $B$ adsorption data and the parameters obtained were related to the chemical attributes by multiple linear regression equations. Boron maximum adsorption capacity (BMAC) and the complexation constant for the $\mathrm{SH}_{3} \mathrm{BO}_{4}$-inner-sphere complex ( $\mathrm{LogK}_{\mathrm{B}}$ ) could be predicted under all experimental conditions. The $\mathrm{Al}_{\mathrm{c}}$ content was the main soil chemical attribute associated with the BMAC under the conditions evaluated and the $\operatorname{LogK}_{\mathrm{B}-}$ (int) in untreated and treated samples.

Keywords: FITEQL, chemical properties, mineralogy
\end{abstract}

\section{Introduction}

Boron is a micronutrient for plants required for several biochemical processes (Cakmak and Romheld, 1997). Boron deficiency is a widespread problem in relatively humid areas, especially in sandy soils. On the other hand, $B$ toxicity tends to occur in arid zones (Gupta et al., 1985; Goldberg, 2004) due to anthropic activity (fertilization and irrigation).

Boron content in the soil solution is usually controlled by adsorption reactions (Goldberg, 1997). Su and Suarez (1995), based on information obtained from electrophoretic mobility and Fourier Transform Infrared Spectroscopy, suggested that $B$ can be adsorbed both as $\mathrm{B}(\mathrm{OH})_{3}$ and $\mathrm{B}(\mathrm{OH})_{4}{ }^{-}$with trigonal and tetrahedral coordination, respectively. The relative proportion of $\mathrm{B}(\mathrm{OH})_{3}$ and $\mathrm{B}(\mathrm{OH})_{4}{ }^{-}$adsorption varies depending on the solution $\mathrm{pH}$. At $\mathrm{pH}$ values < $\mathrm{pKa}(9.3), \mathrm{B}(\mathrm{OH})_{3}$ is the predominant solution form, while above this $\mathrm{pH}$ the predominant form in solution is $\mathrm{B}(\mathrm{OH})_{4}{ }^{-}$(Sposito, 2008).

The main $B$ adsorption mechanism on $\mathrm{Fe}$ and $\mathrm{Al}$ oxides, kaolinite and probably on SOM is the formation of inner-sphere surface complexes (Goldberg et al., 1993; Su and Suarez, 1995). However, $B$ can be adsorbed by formation of outer-sphere complexes on montmorillonite and poorly crystalline iron oxides (Goldberg et al., 1993; Su and Suarez, 1995).

The soil organic matter (SOM) constituents play a key role in the dynamics of $B$ adsorption in soils (Lemarchand et al., 2005); however, their importance is still controversial. A number of authors have correlated the SOM content to increased $B$ adsorption (Sharma et al., 2006; Yermiyaho et al., 1995), while other authors have found increases in $B$ adsorption after removal of SOM (Marzadori et al., 1991; Sarkar et al., 2014).

Boron adsorption data can be described by a variety of empirical models that do not provide a molecular description of adsorption processes. On the other hand, surface complexation models use an equilibrium approach to define surface species, chemical reactions, mass and charge balances (Goldberg, 2005). Boron adsorption has been successfully described using the constant capacitance model for adsorption isotherms and envelopes (Goldberg, 2004; Goldberg and Glaubig, 1986; Goldberg, 1999; Goldberg et al., 2000), but, to our knowledge, there has been no paper published comparing the constant capacitance model for $B$ adsorption in tropical and temperate soils before and after removal of soil organic matter.

The removal of SOM can influence the adsorption of $B$ and the ability of surface complexation models (SCMs) to fit sets of data obtained from adsorption envelopes. Hydroxyls associate with ferrol, aluminol and silanol surface functional groups-SFG on iron and aluminum oxides and broken edges of clay minerals such as kaolinite, usually blocked by the SFG from organic matter will be ready for boron adsorption after SOM removal. This study aimed to evaluate the effects of SOM removal with sodium hypochlorite on $B$ adsorption in soil samples with contrasting mineralogy and to relate it to soil chemical attributes fitting the Langmuir and the constant capacitance model to the isotherm and envelope data. 


\section{Materials and Methods}

\section{Soil sampling}

Boron adsorption was investigated using five surface soil samples (Natric Palexeralf, Aridic Paleustalf, Xeric Torrifluvent, Rhodic Eutroperox, and Anionic Acroperox) with different origins and soil attributes. Soil locations and classification are given in Table 1.

\section{Organic matter removal from soils}

Soil organic matter (SOM) from air dried fine earth-ADFE $(<2 \mathrm{~mm})$ was removed with a sodium hypochlorite $(\mathrm{NaClO})$ solution containing $6 \%$ active chlorine, freshly adjusted to $\mathrm{pH} 9.5$ (Anderson, 1963). The excess residual sodium in the soils was removed by successive washings with distilled and deionized water (10 times) and twice with $\mathrm{NaNO}_{3}(0.01 \mathrm{M})$. Untreated samples were also washed with $\mathrm{NaNO}_{3}(0.01 \mathrm{M})$ to keep the ionic strength constant between treated and untreated samples and to have the same ions on the exchange complex. Subsequently, the samples were dried in the oven $\left(65^{\circ} \mathrm{C}\right)$, ground with a mortar and pestle, and sieved through a $0.50 \mathrm{~mm}$ sieve. These samples were stored for subsequent analysis.

Inorganic carbon (IC) content was determined using a carbon coulometer with an acidification module and was heated to verify the efficiency of the removal procedure. Total carbon (TC) was determined by furnace combustion at $950{ }^{\circ} \mathrm{C}$. Organic $\mathrm{C}$ was determined by the difference between TC and IC.

\section{Chemical and mineralogical analyses}

Cation exchange capacity (CEC) was determined using the method for arid-zone soils (Rhoades, 1982). Sodium concentrations were determined by inductively coupled plasma (ICP) optical emission spectrometry (OES) on a ICP-OES Spectrometer and $\mathrm{Cl}$ was determined using a Labconco Digital Chloridometer.

The free $\mathrm{Fe}$ and $\mathrm{Al}$ oxides $\left(\mathrm{Fe}_{c}\right.$ and $\left.\mathrm{Al}_{\mathrm{c}}\right)$ were determined using two different methods. The first one is described by Coffin (1963) and is usually applied to temperate soils with low $\mathrm{Fe}$ content. Aluminum, $\mathrm{Al}_{\mathrm{c}^{\prime}}$ and iron, $\mathrm{Fe}_{\mathrm{c}}$ concentrations in the extracts were deter- mined by ICP-OES Spectrometer. The second extraction to remove the free iron oxides was performed using Na-citrate-bicarbonate-dithionite (Mehra and Jackson, 1960). This method is extensively used in tropical soils with higher percentages of Fe oxides. Aluminum $\left(\mathrm{Al}_{\mathrm{d}}\right)$ and iron $\left(\mathrm{Fe}_{\mathrm{d}}\right)$ concentrations in the extracts were determined by atomic absorption spectrometry. The residues from solids from both treatments were washed with deionized water. By means of siphoning and sieving, clay, silt and sand fractions were separated. The samples were dried at $65{ }^{\circ} \mathrm{C}$ to constant weight. Subsequently, the presence of clay minerals and aluminum oxide were evaluated by XRD. The powdered samples were analyzed by X-ray diffraction (XRD), using a Co source and a graphite monochromator. Samples were analyzed in step mode in the angular range of 3 to $100^{\circ} 2 \theta$, each $0.02^{\circ} 2 \theta$ and $3 \mathrm{sec}$ per step. The XRD patterns were analyzed and minerals were identified using mineral diffraction planes according to Moore and Reynolds (1997) and Whittig and Alardice (1986) for silicates and Costa and Bigham (2009) for iron oxides. The mineral distribution in the soil sample was determined using selected isolated diffraction planes of each mineral, their relative intensity and the area of each peak in proportion to the amount of each mineral present in the respective soil using Grams 8.0 ${ }^{\circledR}$ Software Suite.

Total specific surface area (SSA) was measured using ethylene-glycol-mono-ethyl-ether (EGME) adsorption (Cihacek and Bremner, 1979).

\section{Adsorption experiments}

Boron adsorption experiments were carried out in batch systems to determine adsorption envelopes and isotherms. For the envelopes, five grams of ADFE were added to $50 \mathrm{~mL}$ polypropylene centrifuge tubes and equilibrated with $25 \mathrm{~mL}$ of $0.05,0.1$ or $1 \mathrm{M} \mathrm{NaNO}_{3}$ solution by shaking for $20 \mathrm{~h}$ on a variable speed reciprocating shaker. This solution contained $0.463 \mathrm{mmol} \mathrm{L}^{-1} B$ $\left(\mathrm{H}_{3} \mathrm{BO}_{3}\right)$ and was adjusted to the desired $\mathrm{pH}$ range $(2$ - 12) using $2 \mathrm{M} \mathrm{HNO}_{3}$ or $2 \mathrm{M} \mathrm{NaOH}$ for $0.05 \mathrm{M} \mathrm{NaNO}_{3}$ solution and $4 \mathrm{M} \mathrm{HNO}_{3}$ or $4 \mathrm{M} \mathrm{NaOH}$ for 0.1 and $1 \mathrm{M}$ $\mathrm{NaNO}_{3}$ solution. For the isotherms, six grams of ADFE were added to $50 \mathrm{~mL}$ polypropylene centrifuge tubes

Table 1 - Soil classifications using Embrapa (2018) and Soil Taxonomy systems (2014), acronyms, and location (year collected) of the five soils.

\begin{tabular}{lc}
\hline \multicolumn{1}{c}{ Embrapa (2018) } & Acronym \\
\hline NATRIC PLANOSOL Typical salic, clayey & SNk \\
CHROMIC LUVISOL Typical carbonatic, medium clayey & TCk \\
FLUVIC NEOSOL Typical carbonatic, clayey & RYk \\
RED LATOSOL Chernosolic eutroferric, very clayey & LVef \\
BROWN LATOSOL Typical dystrophic, very clayey & SBil Taxonomy (2014) \\
\hline & Location \\
\hline Fine, smectitic, thermic Natric Palexeralf - LAS FLORES & California, USA (1968) \\
Fine-loamy, mixed, superactive, thermic Aridic Paleustalf - AMARILLO & Texas, USA (1963) \\
Fine, mixed, superactive, calcareous, mesic Xeric Torrifluvent - CHRISTIANBURG & Wyoming, USA (1968) \\
Very-fine, kaolinitic, subactive, isohyperthermic Humic Rhodic Eutroperox - PALOTINA & Paraná, Brazil (2014) \\
Very-fine, alitic, subactive, isothermic Anionic Acroperox - GUARAPUAVA & Paraná, Brazil (2014) \\
\hline
\end{tabular}


and equilibrated with $15 \mathrm{~mL}$ of a $0.05 \mathrm{M} \mathrm{NaNO}_{3}$ solution by shaking for $20 \mathrm{~h}$ on a variable speed reciprocating shaker. These solutions contained $0,0.231,0.463$, $0.926,1.389,1.853,2.315,2.778,3.241,3.704,4.167$ and $4.630 \mathrm{mmol} \mathrm{L}^{-1} \mathrm{~B}\left(\mathrm{H}_{3} \mathrm{BO}_{3}\right)$ and had been adjusted to $\mathrm{pH} 7.0$ using $2 \mathrm{M} \mathrm{HNO}_{3}$ or $2 \mathrm{M} \mathrm{NaOH}$ for $0.05 \mathrm{M}$ $\mathrm{NaNO}_{3}$ solutions, before starting the experiment using the needed concentration to reach this $\mathrm{pH}$ in the equilibrium solution after $20 \mathrm{~h}$. Additions of acid or base changed the total volumes by $<2 \%$. After the reaction, the samples were centrifuged at $8,000 \mathrm{rpm}$ for $20 \mathrm{~min}$, decanted, analyzed for $\mathrm{pH}$, filtered and analyzed for $B$ concentration using a Perkin Elmer Optima 8,000 ICPOES Spectrometer.

\section{Empirical modeling data}

The isotherm model parameters were obtained by non-linear optimization using the $\mathrm{SAS}^{\circledR}{ }^{\circledR}$ software Suite (Statistical Analysis System, 1999) routine NLIN using the Marquardt optimization scheme. However, this routine does not calculate the coefficient of determination $\left(R^{2}\right)$. This value was obtained by a routine Proc Reg procedure by means of linear regression between observed and predicted values.

The use of the Langmuir isotherm in the nonlinear optimization improves the model fit (Goldberg and Foster, 1991). The Langmuir isotherm model is described by the following equation:

$\mathrm{x}=\frac{{\text { BMAC } \mathrm{k}_{\mathrm{B}} \mathrm{C}}^{1+\mathrm{k}_{\mathrm{B}} \mathrm{C}}}{\mathrm{m}}$

where " $\mathrm{x}$ " is the $B$ adsorbed quantity ( $\mu \mathrm{mol} \mathrm{g}{ }^{-1}$ soil), BMAC the $B$ maximum adsorption capacity $\left(\mu \mathrm{mol} \mathrm{g}{ }^{-1}\right)$, "c" the $B$ solution equilibrium concentration $\left(\mathrm{mmol} \mathrm{L}^{-1}\right)$, and $\mathrm{k}_{\mathrm{B}}$ the constant related to the affinity coefficient $\left(\mathrm{L} \mathrm{mmol}^{-1}\right)$.

\section{Chemical modeling data}

The constant capacitance model contains the following assumptions: All ions, including protons and hydroxyls, adsorb in one surface plane forming innersphere surface complexes. No surface complexes are formed with ions from the background electrolyte. The constant ionic medium reference state determines the activity coefficients of the aqueous species. Surface complexes exist in a chargeless environment in the standard state. The relationship between surface charge $(\sigma)$ and surface potential $(\psi)$ is linear and given by the following formula:

$$
\sigma\left(\frac{\mathrm{C} \mathrm{SSA} a}{\mathrm{~F}}\right) \psi
$$

where $\mathrm{C}$ is the capacitance $\left(\mathrm{F} \mathrm{m}^{-2}\right)$, SSA the total specific surface area $\left(\mathrm{m}^{2} \mathrm{~g}^{-1}\right)$, " $a$ " the particle concentration $\left(\mathrm{g} \mathrm{L}^{-1}\right), F$ the Faraday constant $\left(96.485 \mathrm{C} \mathrm{mol}_{\mathrm{c}}^{-1}\right), \sigma$ the surface charge $\left(\mathrm{mol} \mathrm{L}^{-1}\right)$, and $\psi$ the surface potential $(\mathrm{V})$. In the present application of the constant capacitance model to $B$ adsorption, the following surface complexation reactions were considered:
$\mathrm{SOH}_{(\mathrm{s})}+\mathrm{H}^{+} \rightleftarrows \mathrm{SOH}_{2 \mid \mathrm{s})}^{+}$

$\mathrm{SOH}_{(\mathrm{s})} \rightleftarrows \mathrm{SO}_{(\mathrm{s})}^{-}+\mathrm{H}^{+}$

$\mathrm{SOH}_{(\mathrm{s})}+\mathrm{H}_{3} \mathrm{BO}_{3(\mathrm{aq})} \rightleftarrows \mathrm{SH}_{2} \mathrm{BO}_{3(\mathrm{~s})}+\mathrm{H}_{2} \mathrm{O}$

$\mathrm{SOH}_{(\mathrm{s})}+\mathrm{H}_{3} \mathrm{BO}_{3(\mathrm{aq})} \rightleftarrows \mathrm{SH}_{3} \mathrm{BO}_{4(s)}^{-}+\mathrm{H}^{+}$

where $\mathrm{SOH}$ represents reactive surface hydroxyls on oxides and clay minerals in the soil. Both trigonal and tetrahedral $B$ surface species were included, consistent with the experimental spectroscopic results of $\mathrm{Su}$ and Suarez (1995). Intrinsic equilibrium constant expressions for the surface complexation reactions are, respectively:

$\mathrm{K}_{+}($int $)=\frac{\left[\mathrm{SOH}_{2}^{+}\right]}{[\mathrm{SOH}]\left[\mathrm{H}^{+}\right]} \exp (\mathrm{F} \psi / \mathrm{RT})$

$\mathrm{K}_{-}(\mathrm{int})=\frac{\left[\mathrm{SO}^{-}\right]\left[\mathrm{H}^{+}\right]}{[\mathrm{SOH}]} \exp (-\mathrm{F} \psi / \mathrm{RT})$

$\mathrm{K}_{\mathrm{B}+}($ int $)=\frac{\left[\mathrm{SH}_{2} \mathrm{BO}_{3}\right]}{[\mathrm{SOH}]\left[\mathrm{H}_{3} \mathrm{BO}_{3}\right]}$

$\mathrm{K}_{\mathrm{B}-}($ int $)=\frac{\left[\mathrm{SH}_{3} \mathrm{BO}_{4}^{-}\right]\left[\mathrm{H}^{+}\right]}{[\mathrm{SOH}]\left[\mathrm{H}_{3} \mathrm{BO}_{3}\right]} \exp (-\mathrm{F} \psi / \mathrm{RT})$

where $\mathrm{R}$ is the molar gas constant $\left(8.314 \mathrm{~J} \mathrm{~mol}^{-1} \mathrm{~L}^{-1}\right)$, $\mathrm{T}$ the absolute temperature $(\mathrm{K})$, and square brackets [ ] indicate concentrations $\left(\mathrm{mol} \mathrm{L}^{-1}\right)$ while parentheses () represent activities. The exponential terms can be considered as solid-phase activity coefficients correcting for the charges on the surface complexes. Mass balance for the reactive surface functional groups is:

$[\mathrm{SOH}]_{\mathrm{T}}=[\mathrm{SOH}]+\left[\mathrm{SOH}_{2}^{+}\right]+\left[\mathrm{SO}^{-}\right]+\left[\mathrm{SH}_{2} \mathrm{BO}_{3}\right]+\left[\mathrm{SH}_{3} \mathrm{BO}_{4}^{-}\right]$

Charge balance is:

$\sigma=\left[\mathrm{SOH}_{2}^{+}\right]+\left[\mathrm{SO}^{-}\right]+\left[\mathrm{SH}_{3} \mathrm{BO}_{4}^{-}\right]$

where $\sigma$ has units of $\mathrm{mol} \mathrm{L}^{-1}$.

The computer program FITEQL 4.0 (Herbelin and Westall, 1999) was used to fit B surface complexation constants to the experimental $B$ adsorption data. FITEQL 4.0 uses a nonlinear least squares optimization routine to fit equilibrium constants to experimental data. Initial input parameter values for the constant capacitance model were capacitance: $\mathrm{C}=1.06 \mathrm{~F} \mathrm{~m}^{2}$ (Westall and Hohl, 1980) and the Faraday constant ( $F=96.485$ $\mathrm{C} \mathrm{mol}_{\mathrm{c}}^{-1}$ ). The total number of reactive surface hydroxyl groups, $[\mathrm{SOH}]_{\mathrm{T}}$ was optimized by FITEQL 4.0 using the constant capacitance model in a previous optimization using the values for $\mathrm{H}^{+}\left(\mathrm{mol} \mathrm{L}^{-1}\right)$ and $\mathrm{pH}$ from $B$ adsorption envelope experiments. Surface complexation constant modeling of $B$ adsorption is sensitively dependent on surface site density (Goldberg, 1991). 
The quality of fit was determined from the global variance (Vy):

$$
\mathrm{V}_{\mathrm{y}}=\frac{\mathrm{SQ}}{\mathrm{GL}}
$$

where SQ is the sum of squares and GL degrees of freedom (Herbelin and Westall, 1999).

\section{Statistical analysis}

Pearson's correlation coefficients and multiple linear regression analysis, coefficient of determination $\left(\mathrm{R}^{2}\right)$, coefficient of correlation $(\mathrm{r})$ and $\mathrm{p}$-values were calculated using the Proc Corr and Proc Reg procedures from the SAS ${ }^{\circledR}$ software suite (Statistical Analysis System, version 9.2).

\section{Results and Discussion}

\section{Soil organic matter removal}

The SOM removal procedure was $80 \%$ (Anionic Acroperox) to $95 \%$ (Xeric Torrifluvent and Rhodic Eutroperox) efficient (Table 2). The incomplete removal of the SOM increases with the degree of humification of the humic substances (Zimmermann et al., 2007). After SOM removal, CEC values were found to decrease for Natric Palexeralf, Rhodic Eutroperox and Anionic Acroperox soils, while for Aridic Paleustalf and Xeric Torrifluvent soils the CEC values remained similar. The differences in CEC values for these soils are within the analytical error margin (Table 2). The SSA values with the removal of SOM decreased for Natric Palexeralf and Xeric Torrifluvent soils and increased for Rhodic Eutroperox and Anionic Acroperox soils, and there was no change for the Aridic Paleustalf. SOM removal promoted precipitation of poorly crystalline forms of $\mathrm{Fe}$ oxides in one of the soils when considering the $\mathrm{Fe}_{\mathrm{d}}$ and $\mathrm{Al}_{\mathrm{d}}$ content (Rhodic Eutroperox).

The XRDs showed certain mineralogical changes in the samples studied after removal of organic matter. Most prominent are the intense reflections due to feldspars in the Natric Palexeralf and Aridic Paleustalf soils, the decreases in the intensity of the quartz peak, and apparent changes in the smectite diffraction patterns in the Xeric Torrifluvent soil (Figure 1). The mineral composition of the soil samples was classified as smectitic, mixed, kaolinitic or illitic (Soil Survey Staff, 2014) (Figure 1, Table 3).

Table 2 - Chemical attributes of untreated and treated soils samples with sodium hypochlorite.

\begin{tabular}{|c|c|c|c|c|c|c|c|c|c|}
\hline Soils & Depth & CEC & SSA & IC & OC & $\mathrm{Fe}_{\mathrm{c}}$ & $\mathrm{Al}_{\mathrm{c}}$ & $\mathrm{Fe}_{\mathrm{d}}$ & $\mathrm{Al}_{\mathrm{d}}$ \\
\hline & $\mathrm{cm}$ & $\mathrm{mmol}_{\mathrm{c}} \mathrm{kg}^{-1}$ & $\mathrm{~km}^{2} \mathrm{~kg}^{-1}$ & 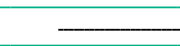 & & $\mathrm{c}-\mathrm{g}$ & $\mathrm{kg}^{-1} \ldots$ & 0 & - \\
\hline & & & & & Untreated sa & amples & & & \\
\hline $\begin{array}{l}\text { Rhodic } \\
\text { Eutroperox }\end{array}$ & $0-20$ & $97.507 \pm 0.037$ & $0.070 \pm 0.002$ & $0.000 \pm 0.000$ & $20.550 \pm 0.550$ & $17.364 \pm 0.285$ & $1.016 \pm 0.026$ & $6110.781 \pm 1.899$ & $6.828 \pm 0.468$ \\
\hline $\begin{array}{l}\text { Anionic } \\
\text { Acroperox }\end{array}$ & $0-20$ & $144.056 \pm 4.752$ & $0.104 \pm 0.000$ & $0.000 \pm 0.000$ & $32.850 \pm 0.150$ & $10.837 \pm 0.330$ & $2.884 \pm 0.109$ & $9102.387 \pm 0.205$ & $27.032 \pm 0.785$ \\
\hline & & & & Sampl & les treated with so & odium hypochlorite & & & \\
\hline $\begin{array}{l}\text { Natric } \\
\text { Palexeralf }\end{array}$ & $0-12$ & $151.800 \pm 0.960$ & $0.094 \pm 0.006$ & $0.706 \pm 0.101$ & $3.244 \pm 0.159$ & $2.311 \pm 0.137$ & $0.506 \pm 0.019$ & $4.841 \pm 0.392$ & $1.255 \pm 0.065$ \\
\hline $\begin{array}{l}\text { Aridic } \\
\text { Paleustalf }\end{array}$ & $0-7$ & $62.117 \pm 4.733$ & $0.058 \pm 0.002$ & $0.000 \pm 0.000$ & $0.428 \pm 0.021$ & $2.027 \pm 0.109$ & $0.375 \pm 0.043$ & $4.572 \pm 0.191$ & $1.357 \pm 0.041$ \\
\hline $\begin{array}{l}\text { Xeric } \\
\text { Torrifluvent }\end{array}$ & $0-6$ & $542.246 \pm 10.395$ & $0.158 \pm 0.007$ & $2.525 \pm 0.426$ & $0.400 \pm 0.071$ & $2.943 \pm 0.170$ & $0.685 \pm 0.007$ & $6.007 \pm 0.601$ & $1.361 \pm 0.063$ \\
\hline $\begin{array}{l}\text { Rhodic } \\
\text { Eutroperox }\end{array}$ & $0-20$ & $33.355 \pm 0.736$ & $0.073 \pm 0.000$ & $0.000 \pm 0.000$ & $1.000 \pm 0.000$ & $18.020 \pm 2.010$ & $1.103 \pm 0.081$ & $80.494 \pm 0.130$ & $7.652 \pm 1.231$ \\
\hline $\begin{array}{l}\text { Anionic } \\
\text { Acroperox }\end{array}$ & $0-20$ & $66.096 \pm 4.002$ & $0.110 \pm 0.001$ & $0.000 \pm 0.000$ & $6.200 \pm 0.000$ & $7.798 \pm 0.001$ & $2.269 \pm 0.018$ & $8 \quad 68.898 \pm 2.794$ & $24.238 \pm 1.730$ \\
\hline
\end{tabular}

Table 3 - Mineralogy and particles size distribution of the soils.

\begin{tabular}{|c|c|c|c|c|c|c|c|c|c|c|c|c|c|c|c|}
\hline Soils & Clay & Silt & Sand & $\mathrm{Ka}$ & $\mathrm{Mi}$ & $2: 1$ & Qz & Gi & $\mathrm{Fd}$ & $\mathrm{Hm}$ & Ap & $\mathrm{Im}$ & Un & $\mathrm{Fe}_{2} \mathrm{O}_{3}$ & $\mathrm{Al}_{2} \mathrm{O}_{3}$ \\
\hline & & $\%$ & & & & & & $\%$ & & & & & & & \\
\hline Natric Palexeralf & 35.88 & 29.90 & 34.23 & 9.55 & 5.65 & 15.88 & 52.38 & 0.00 & 14.44 & 0.00 & 1.13 & 0.00 & 0.00 & 0.83 & 0.25 \\
\hline Aridic Paleustalf & 25.19 & 12.60 & 62.21 & 3.60 & 3.00 & 5.01 & 83.03 & 0.00 & 0.92 & 0.00 & 0.00 & 0.00 & 3.56 & 0.63 & 0.23 \\
\hline Xeric Torrifluvent & 69.97 & 24.69 & 5.34 & 7.43 & 5.53 & 20.97 & 64.28 & 0.00 & 0.62 & 0.00 & 0.00 & 0.00 & 0.00 & 0.89 & 0.29 \\
\hline Rhodic Eutroperox & 71.42 & 13.16 & 15.43 & 41.58 & 0.00 & 0.00 & 37.66 & 0.00 & 0.38 & 3.25 & 0.00 & 0.00 & 0.00 & 15.84 & 1.29 \\
\hline Anionic Acroperox & 74.32 & 20.64 & 5.03 & 24.38 & 0.00 & 4.68 & 28.68 & 20.53 & 0.00 & 0.00 & 0.00 & 1.98 & 0.00 & 14.64 & 5.11 \\
\hline
\end{tabular}

$\mathrm{Ka}=$ kaolinite; $\mathrm{Mi}$ = mica; $2: 1$ = smectite and/or vermiculite; $\mathrm{Qz}=$ quartz; Gi = gibbsite; Fd = feldspar; $\mathrm{Hm}=$ hematite; $\mathrm{Ap}=$ amphibole; Im = ilmenite; Un = unidentified mineral; $\mathrm{Fe}_{2} \mathrm{O}_{3},=$ iron oxides; $\mathrm{Al}_{2} \mathrm{O}_{3}=$ aluminum oxides, clay, silt, and sand content. 

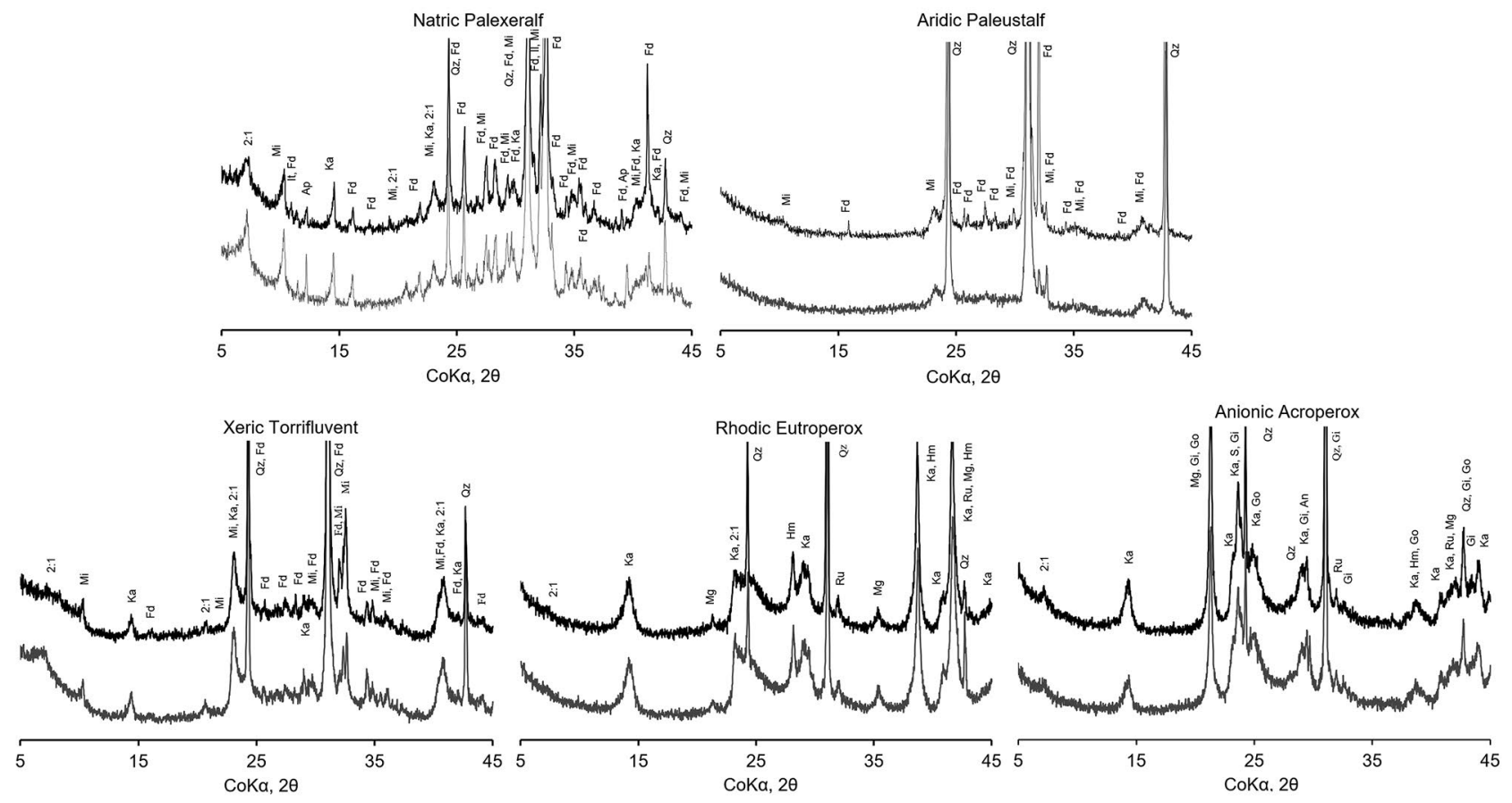

Figure 1 - X-ray diffractometry for soil samples. Gray lines refer to untreated samples and black lines refer to treated samples with sodium hypochlorite. Ap, amphibole; An, anatase; Fd, feldspar; Go, goethite; Gi, gibbsite; Hm, hematite; It, illite; Ka, kaolinite; Mi, mica; Mg, magnetite or maghemite, 2:1, smectite and/or vermiculite; Qz, quartz; Ru: rutile. In this figure albite, anorthite and orthoclase were identified as feldspar.

Characterization of the treated and untreated soils The studied samples (treated and untreated) have a wide range of CEC (68.70 to $\left.533.26 \mathrm{mmol}_{\mathrm{c}} \mathrm{kg}^{-1}\right), \mathrm{SSA}$ (0.058 to $0.180 \mathrm{~km}^{2} \mathrm{~kg}^{-1}$ ), OC (4.1 to $\left.32.8 \mathrm{~g} \mathrm{~kg}^{-1}\right), \mathrm{Fe}_{\mathrm{c}}(2.03$ to $\left.18.02 \mathrm{~g} \mathrm{~kg}^{-1}\right), \mathrm{Al}_{\mathrm{c}}\left(0.311\right.$ to $\left.2.88 \mathrm{~g} \mathrm{~kg}^{-1}\right), \mathrm{Fe}_{\mathrm{d}}(4.43$ to $110.78 \mathrm{~g} \mathrm{~kg}^{-1}$ ), and $\mathrm{Al}_{\mathrm{d}}$ contents (1.22 to $27.032 \mathrm{~g} \mathrm{~kg}^{-1}$ ). The IC levels are relatively low when compared with the soils studied by Goldberg et al. (2000).

Aluminum, $\mathrm{Al}_{\mathrm{c}}$ and $\mathrm{Al}_{\mathrm{d}}$ both had high significant correlation $(\mathrm{r}=0.99, p<0.05)$ as $\mathrm{did} \mathrm{Fe}_{\mathrm{c}}$ and $\mathrm{Fe}_{\mathrm{d}}(\mathrm{r}=$ $0.91, p<0.05$ ). However, the $\mathrm{Al}_{\mathrm{c}}$ and $\mathrm{Fe}_{\mathrm{c}}$ contents (Table 2) are related to the portions of $\mathrm{Fe}$ and $\mathrm{Al}$ present in organic matter-OM and poorly crystalline Fe oxides. The Coffin (1963) procedure (one extraction) was not able to remove all the free-Fe oxides compared to the Mehra and Jackson (1960) procedure which was repeated until the soil turned whitish. However, $4 \%$ of hematite still remained in the Rhodic Eutroperox soil after this procedure (Table 3), and was probably present in the coarse silt fraction.

When additional extractions were made using the Coffin (1963) method (around six for Brazilian soils), the iron oxide content extracted was closely related to that extracted by the Mehra and Jackson (1960) procedure (data not included).

\section{Boron adsorption}

The $\mathrm{pH}$ was set to seven in the adsorption isotherms to allow for comparison between the treated and untreated samples. The SOM removal procedure increased the $\mathrm{pH}$ in the soils (8.5-9.0), when it was naturally low (around pH 6 in Brazilian soil samples). Furthermore, this procedure allows for the evaluation of the influence of mineralogy without considering the $\mathrm{pH}$ effect. The $\mathrm{pH}$ values showed some variation after adsorption. Average $\mathrm{pH}$ was $7.11 \pm 0.12$ for all samples. Not treated and treated soil samples presented very small variations among soils with average values of $7.07 \pm$ 0.10 and $7.16 \pm 0.13$, respectively.

Boron maximum adsorption capacity (BMAC) ranged from 1.7 to $11.05 \mu \mathrm{mol} \mathrm{g}^{-1}$ (Table 4). These values are in agreement with Goldberg and Suarez (2012) and Soares et al. (2008). However, they are higher than the BMAC values observed by Alleoni and Camargo (2000).

Untreated North American soils had higher BMAC values than the treated ones (Figure 2, Table 4), highlighting the importance of SOM in $B$ adsorption in temperate soils where the mineralogy is based on feldspars and 2:1 aluminosilicates, having predominant negative permanent charges and small amounts of $\mathrm{Fe}$ and $\mathrm{Al}$ oxides (Tables 2 and 3). These results are in agreement with those described by Olson and Berger (1947) for an Entisol and an Alfisol from the USA.

For Brazilian soils, where $\mathrm{Fe}$ and $\mathrm{Al}$ oxides contents are important and the clay fraction content is high (Tables 2 and 3), treated samples had higher BMAC values compared to untreated ones (Figure 2, Table 4). This behavior can be related to the presence of positive and $\mathrm{pH}$-dependent charges from the ferrol and aluminol 

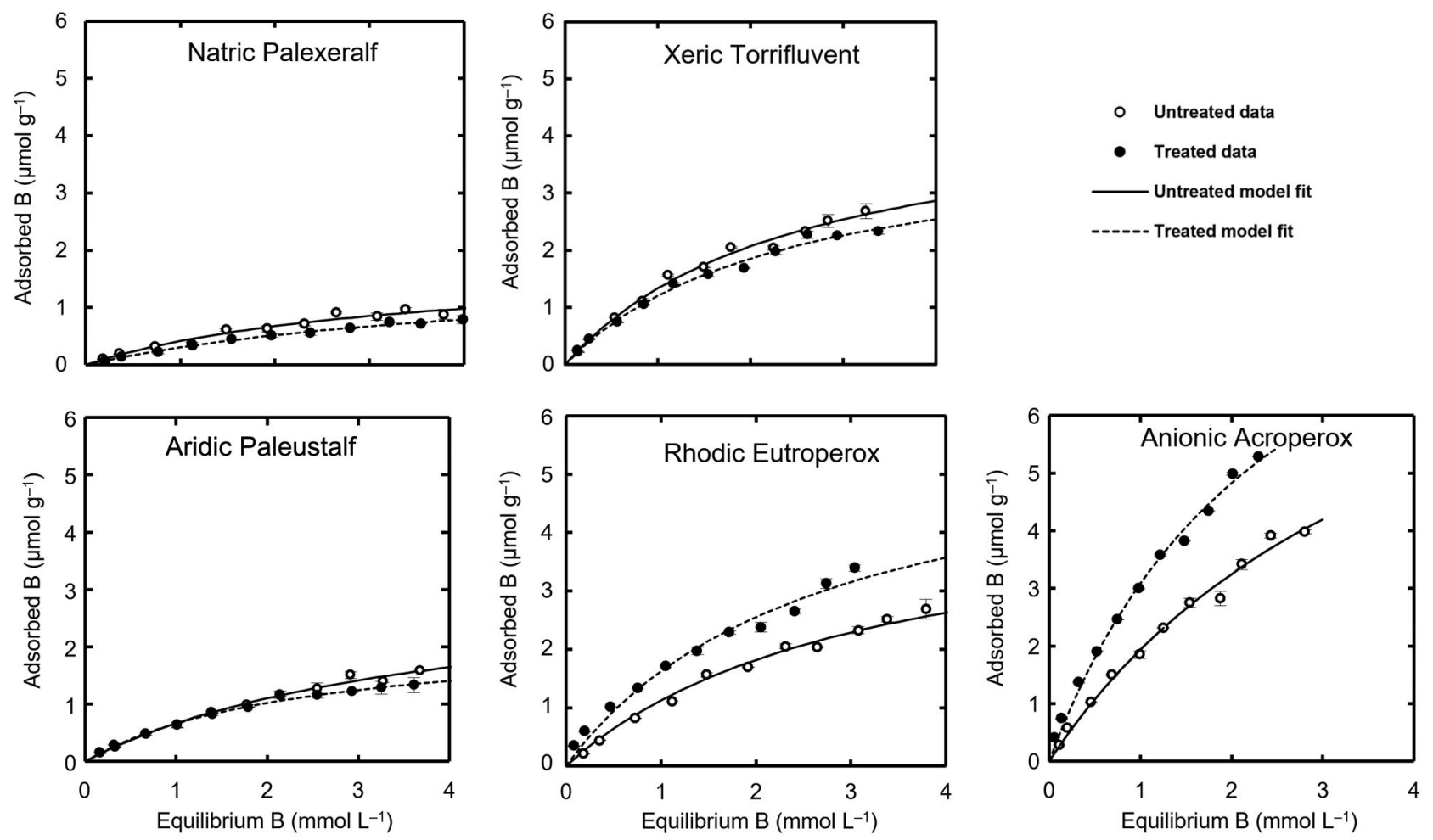

Figure 2 - Boron adsorption Langmuir isotherms for the untreated and treated soil samples with sodium hypochlorite.

Table 4 - Boron maximum adsorption capacity (BMAC) and constants related to the affinity coefficient $(\mathrm{kB})$ obtained by using the Langmuir isotherm fitted with Proc Reg routines from SAS ${ }^{\circledR}$ software (SAS, 1999).

\begin{tabular}{|c|c|c|c|c|c|}
\hline Soils & $\frac{\mathrm{BMAC}}{\mu \mathrm{mol} \mathrm{g}{ }^{-1}}$ & $\frac{\mathrm{kB}}{\mathrm{L} \mathrm{mmol}^{-1}}$ & $\mathrm{R}^{2}$ & $p$ & $\frac{\triangle \mathrm{BMAC}}{\%}$ \\
\hline \multicolumn{6}{|c|}{ Untreated samples } \\
\hline Natric Palexeralf & 1.796 & 0.302 & 0.95 & 0.001 & 94.71 \\
\hline Aridic Paleustalf & 3.251 & 0.256 & 0.98 & 0.001 & 69.14 \\
\hline Xeric Torrifluvent & 4.653 & 0.401 & 1.00 & 0.001 & 86.92 \\
\hline Rhodic Eutroperox & 4.768 & 0.311 & 0.98 & 0.001 & 125.48 \\
\hline Anionic Acroperox & 10.062 & 0.238 & 0.99 & 0.001 & 109.58 \\
\hline \multicolumn{6}{|c|}{$\begin{array}{c}\text { Samples treated with sodium } \\
\text { hypochlorite }\end{array}$} \\
\hline Natric Palexeralf & 1.702 & 0.218 & 0.95 & 0.001 & \\
\hline Aridic Paleustalf & 2.246 & 0.415 & 0.98 & 0.001 & \\
\hline Xeric Torrifluvent & 4.043 & 0.423 & 0.99 & 0.001 & \\
\hline Rhodic Eutroperox & 5.963 & 0.374 & 0.98 & 0.001 & \\
\hline Anionic Acroperox & 11.037 & 0.388 & 1.00 & 0.001 & \\
\hline
\end{tabular}

$\triangle \mathrm{BMAC}=$ Percentage of $B$ adsorption in untreated samples related to mineral fraction (treated sample).

surface functional groups-SFG present in the $\mathrm{Fe}$ and $\mathrm{Al}$ oxides surfaces, and aluminol-SFG present in the broken edges of kaolinite, which contribute to $B$ adsorption. In these soils, the SOM carboxyl and phenolic surface functional groups are insufficient for offseting the mineral surface area occluded due to the interaction between minerals and SOM.
These results are in agreement with those described by Sarkar et al. (2014) for Entisols rich in Al-oxide. These authors also reported decreases in $B$ adsorption after the $\mathrm{Fe}, \mathrm{Al}$, and $\mathrm{Mn}$ oxide removal. Marzadori et al. (1991) found similar results for two Inceptisols and a Vertisol from Italy whose mineralogy was a prevailing 2:1 clay minerals (smectite, illite and chlorite) and quartz. Marzadori et al. (1991) related these results to precipitation of poorly crystalline Al-oxide and to the activation of adsorption sites which were coated by SOM, as described earlier.

SOM is more effective in the adsorption of $B$ in the permanent charge soils (Aridic Paleustalf, Xeric Torrifluvent, Natric Palexeralfs) compared to the $\mathrm{pH}$ dependent charge soils (Rhodic Eutroperox, Anionic Acroperox soils). In these soils, the mineral fraction, independent of surface charge predominance, is responsible for most of the values assigned to BMAC (Table 4).

Boron adsorption envelopes showed an increase in dissolved SOM content (humic acid) as the $\mathrm{pH}$ increased, in the following soils: Rhodic Eutroperox, Natric Palexeralf, and Anionic Acroperox. This behavior was also observed in the adsorption isotherms, but to a lesser degree. However, $B$ adsorbed on dissolved SOM was not quantified, because it was not possible to separate the $B$ adsorbed on humic acid from solution. Therefore, it is possible that the differences found between treated and untreated samples in Brazilian soils are actually smaller than those observed (Figure 2). 
Based on the $B$ adsorption envelopes (Figure 3 ) it is possible to suggest that $B$ adsorption occurs in the presence of positive and negative charges, and increases with $\mathrm{pH}$, with the exception of the Natric Palexeralf soil, where it is not possible to make this assertion, because native $B$ is desorbed below $\mathrm{pH}$ 6.0.

Differences between adsorption values for the envelopes for untreated and treated samples are greater in the 9-9.5 pH range at the location of the $B$ adsorption maxima for the North American soils. For Brazilian soils, this difference is clear between $\mathrm{pH} 4$ and 8.5 (0.05 $\mathrm{M}$ ionic strength) and follows the same behavior previously described for the isotherms (Figure 3).

However, these differences decrease as the ionic strength increases for Brazilian soils. At the $1 \mathrm{M}$ ionic strength, there was no difference between treated and untreated samples for the Anionic Acroperox soil. For the Rhodic Eutroperox soil, $B$ adsorption is higher in the treated sample up to $\mathrm{pH} 8$, when $B$ adsorption becomes higher in the untreated sample (Figure 3). This behavior can also be related to mineralogy and the OM composition. Apparently, SOM present in the Anionic Acroperox, Rhodic Eutroperox, and Natric Palexeralf soils have more negative charges than that in the Xeric Torrifluvent and Aridic Paleustalf soils. This was expected since these soils have higher ferrol and aluminol surface functional groups whose $\mathrm{pH}_{\mathrm{ZPC}}$ is above $\mathrm{pH} 8.0$ (Sposito, 2008). This can also be verified by considering the decrease in the CEC values for these soils after organic matter removal.

High density charges on surface functional groups can prevent $B$ adsorption due to the high quantities of ions needed to compensate this charge which contributes to increasing the thickness of the electrical double layer (Bohinc et al., 2001). When the electrical double layer is compressed by increasing ionic strength, $B$ adsorption increases on $\mathrm{Fe}$ and $\mathrm{Al}$ oxide surfaces, but this happens just above $\mathrm{pH} 6$ and is more evident for the tropical soils Anionic Acroperox and Rhodic Eutroperox.

Below $\mathrm{pH}$ 6, $B$ adsorption decreases with increasing ionic strength for the Xeric Torrifluvent, Anionic Acroperox, and Rhodic Eutroperox treated samples indicating outer-sphere surface complex formation. On the other hand, above this $\mathrm{pH}, B$ adsorption increases or remains constant, indicating inner-sphere surface complex formation (Goldberg and $\mathrm{Su}, 2007$ ).

Assuming that there is no interaction among particles and the removed OC content, it is possible to estimate the $\mathrm{BMAC}$ value for SOM $\left(\mathrm{BMAC}_{\mathrm{SOM}}\right)$ from the difference between the BMAC values of untreated and treated samples (Eq. 14):
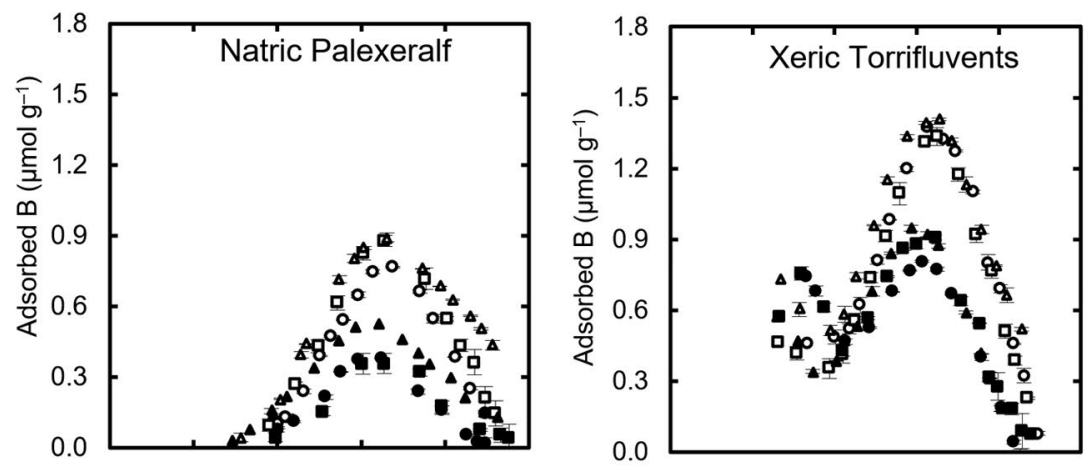

- Untreated $0.05 \mathrm{M}$

- Treated $0.05 \mathrm{M}$

- Untreated $0.1 \mathrm{M}$

- Treated $0.1 \mathrm{M}$

$\Delta$ Untreated $1 \mathrm{M}$

$\triangle$ Treated $1 \mathrm{M}$
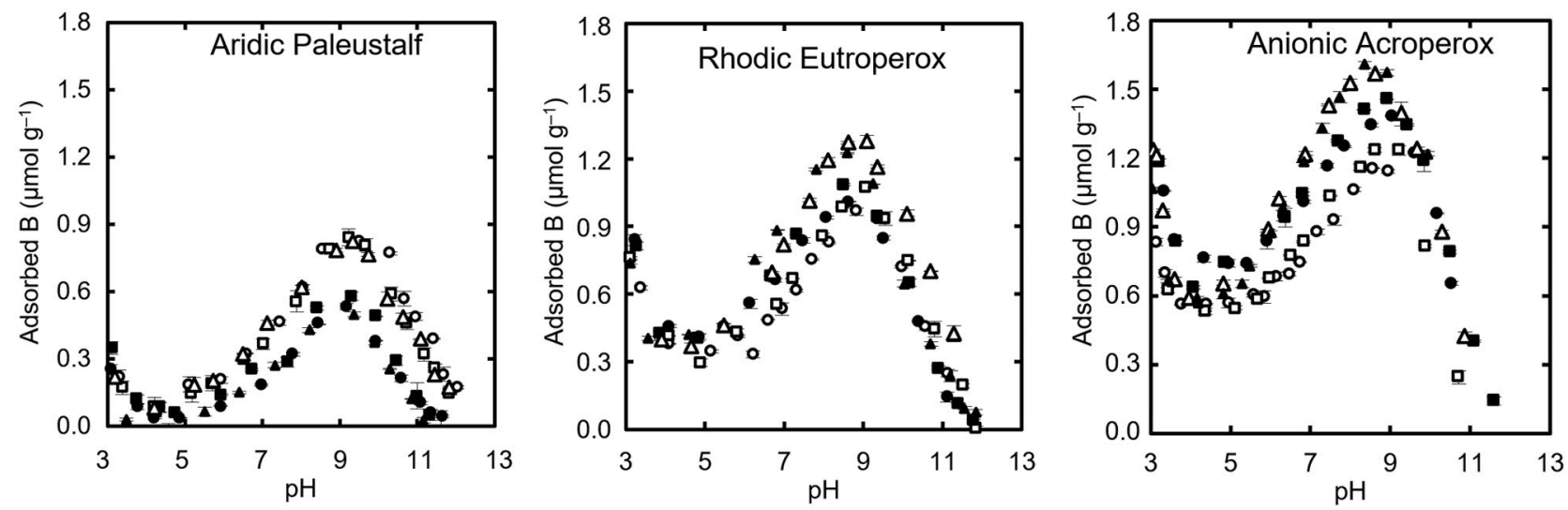

Figure 3 - Boron adsorption envelopes as a function of $\mathrm{pH}$ and ionic strengths in the five soils for untreated and treated samples with sodium hypochlorite. 
$\mathrm{BMAC}_{\mathrm{SOM}}=\left(\mathrm{BMAC}_{\mathrm{U}} \times\left(\mathrm{BMAC}_{\mathrm{T}} \times\left(\frac{100-\mathrm{OC}_{\mathrm{U}-\mathrm{Y}}}{100}\right)\right)\right) \times\left(\frac{100}{\mathrm{OC}_{\mathrm{U}-\mathrm{T}}}\right)$

where $\mathrm{OC}_{\mathrm{U}-\mathrm{T}}$ is the organic carbon removed from soil by the procedure described by Anderson (1963), BMAC the $B$ maximum adsorption on untreated samples and $\mathrm{BMAC}_{\mathrm{T}}$ the $B$ maximum adsorption on treated ones (Tables 2 and 4$)$.

From this calculation, $\mathrm{BMAC}_{\mathrm{SOM}}$ values are 5.75, 82.01 and $274.89 \mathrm{mmol} \mathrm{g}^{-1}$ for the Natric Palexeralf, Xeric Torrifluvent, and Aridic Paleustalf, respectively. The Rhodic Eutroperox and the Anionic Acroperox soils have negative adsorption values, -56.34 and $-25.22 \mu \mathrm{mol} \mathrm{g}^{-1}$, respectively. The positive values measured are higher than the estimated ones, because the organic matter removal procedure exposed the SSA of the 2:1 clay minerals of the temperate soils previously hindered. On the other hand, this calculation just takes into account a portion of the organic matter surface because another portion is interacting with the clay minerals. The negative values of $\mathrm{BMAC}_{\mathrm{SOM}}$ for the two tropical soils reinforce the hypothesis of the presence of positive surface charge on the remaining humic substances.

$\mathrm{BMAC}_{\mathrm{SOM}}$ values observed for the Xeric Torrifluvent and the Aridic Paleustalf are high, considering the BMAC values determined by $\mathrm{Gu}$ and Lowe (1990) for humic acid at $\mathrm{pH} 6.7\left(10-42 \mu \mathrm{mol} \mathrm{g}^{-1}\right)$ and the $\mathrm{pH}$ at which the adsorption was measured (7.0). The same authors found higher maximum values at $\mathrm{pH} 8.8$ ranging from 73 to $207 \mu \mathrm{mol} \mathrm{g}^{-1}$.

Pearson's correlation coefficients between the mineralogy of the soils and the BMAC for the untreated and treated samples did not present any significative $(p$ $>0.05$ ) correlation with kaolinite, gibbsite, mica, quartz, feldspar or total free iron oxides (Fed) contents. When all samples are considered, significant $(p<0.05)$ positive correlation was observed between BMAC and the kaolinite $(\mathrm{r}=0.55 ; p<0.01)$ content, and negative correlation was observed with the quartz $(\mathrm{r}=-0.71, p<0.05)$ and feldspar $(\mathrm{r}=-0.56, p<0.01)$ contents. These correlations confirm the importance of the variable charge minerals in the boron adsorption with aluminol surface functional group. The increasing occurrence of the silanol surface functional group associated to the quartz and feldspar mineralogy have low affinity for the boron species.

Pearson's correlation coefficients were evaluated for the other soil chemical and mineralogical attributes: $\mathrm{CEC}, \mathrm{SSA}, \mathrm{OC}, \mathrm{IC}, \mathrm{Fe}_{\mathrm{c}^{\prime}} \mathrm{Al}_{\mathrm{c}^{\prime}}$ and BMAC. However, BMAC was only significantly correlated with $\mathrm{Al}_{\mathrm{c}}$ content $\mathrm{V}=$ 0.94, $p<0.05)$ under the conditions evaluated.

An initial regression model for BMAC and $k_{B}$ was specified (Eq. 15):

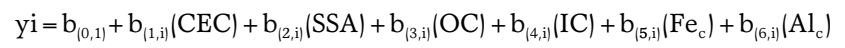

where $y$ represents BMAC and $\mathrm{k}_{\mathrm{B}^{\prime}}, \mathrm{b}_{0}$ through $\mathrm{b}_{6}$ the empirical regression coefficients, and $\varepsilon$ the statistic random error component.

The only attributes found to be statistically significant in the model were $\mathrm{Al}(p<0.01)$ and $\mathrm{OC}(p<$ 0.07) (Table 5) under all the conditions evaluated. The $\mathrm{Al}$ content was the most important component in these equations (partial $\mathrm{R}^{2} \geq 0.90, p<0.05$ ).

Boron adsorption was found to be related to the presence of exchangeable, free, and even the $\mathrm{Al}$ present in the crystal structure of minerals such as allophane and imogolite by several authors (Alleoni and Camargo, 2000; Sims and Bingham, 1968; Bingham et al., 1971). These results can be explained by the higher $B$ affinity of the aluminol groups present on hydroxy-Al (Sims and Bingham, 1968), separate from the clay minerals, because Al-hydroxy exists as an interlayer cation between clay platelets and decreases the contribution of $\mathrm{Al}$ to $B$ adsorption (Keren and Bingham, 1985).

The negative relationship between OC and BMAC in the predicted model (Table 5) can be explained by the difference between $\mathrm{OC}$ contents in the untreated and treated samples and the $\mathrm{BMAC}_{\text {SOM }}(\mathrm{r}=-0.87, p=0.052$, $\left.\mathrm{BMAC}_{\text {SOM }}=-113.2 \mathrm{OC}+240.2\right)$. Non-treated samples with higher OC content adsorb less $B$. This behavior is related to a better surface coverage by SOM in the samples with higher OC content and the presence of more recalcitrant $\mathrm{C}$ in the samples with lower OC content. However, these results are not in agreement with those found by Goldberg et al. (2000), because they worked with only temperate soils which did not have their soil organic matter removed.

The affinity coefficient $\left(\mathrm{k}_{\mathrm{B}}\right)$ constant values were higher in treated samples in Aridic Paleustalf, Xeric Torrifluvent, Rhodic Eutroperox, and Anionic Acroperox, indicating a higher $B$ affinity for the mineral fraction (Table 4). Similar results were observed by Soares et al. (2008), who evaluated surface and subsurface soils. However, the reverse behavior was found in the Natric Palexeralf soil. It was not possible to determine a multiple regression model for $\mathrm{k}_{\mathrm{B}}$ for both the treated and all samples. However, $\mathrm{k}_{\mathrm{B}}$ values can be predicted for the untreated samples, using just the IC in the model (Table 5). Values of $\mathrm{k}_{\mathrm{B}}$ were also positively correlated with CEC in these samples $(\mathrm{r}=0.87, p<0.05)$.

Table 5 - Multiple linear regression models relative to the Boron maximum adsorption capacity (BMAC) and the constant related to the affinity coefficient (kB).

\begin{tabular}{llcc}
\hline Samples & \multicolumn{1}{c}{ Multiple linear regression model } & $\mathrm{R}^{2}$ & Prob. $>\mathrm{F}$ \\
\hline All & $\mathrm{BMAC}=1.514+3.996 \mathrm{Al}_{\mathrm{c}}-0.066 \mathrm{OC}$ & 0.93 & 0.0001 \\
\hline Untreated & $\mathrm{BMAC}=2.711+3.642 \mathrm{Al}_{c}-0.093 \mathrm{OC}$ & 1.00 & 0.0038 \\
\hline Untreated & $\mathrm{K}_{\mathrm{B}}=0.265+0.058 \mathrm{IC}$ & 0.80 & 0.0406 \\
\hline Treated & $\mathrm{BMAC}=0.009+5.853 \mathrm{Al}_{c}-0.387 \mathrm{OC}$ & 1.00 & 0.0014 \\
\hline
\end{tabular}

$\mathrm{Al}_{\mathrm{c}}$, aluminum content (Coffin, 1963); OC = organic carbon; IC = inorganic carbon. 
The constant capacitance model was fit to the $B$ adsorption envelopes data optimizing surface constants for both trigonal and tetrahedral surface configurations of adsorbed $B$ and protonation and deprotonation constants simultaneously (Equations 3 to 6 ) in the $\mathrm{pH}$ range 4 to 12 for the Aridic Paleustalf, the Rhodic Eutroperox, and the Anionic Acroperox in the $\mathrm{pH}$ range 6 to 12 for the Natric Palexeralf and Xeric Torrifluvent. These $\mathrm{pH}$ values varied according to the inflection point (Figure $3)$. In the absence of the trigonal constant, the model converged for the smaller number of samples.

The soils had the following ranges of fitted surface complexation constants: $\operatorname{LogK}_{\mathrm{B}-}$ (int), -5.39 to -8.27; $\log _{+}$(int), 4.29 to $9.16 \operatorname{LogK}_{-}$(int), -12.65 to -8.04 (Table 6). Using the prediction equations of Goldberg et al. (2000) and the chemical properties (Table 1), these ranges should be as follows: $\log \mathrm{K}_{\mathrm{B}-}$ (int), -9.95 to $-8.13 ; \log \mathrm{K}$ (int), 7.70 to $10.82 ; \log \mathrm{K}$ (int), -13.20 to -11.21 . In fact, the values determined for the soils studied show little difference. Part of this behavior can be related to the $[\mathrm{SOH}]_{\mathrm{T}}$ value, which was not calculated the same way and the inclusion of tropical soils rich in $\mathrm{Al}$ and $\mathrm{Fe}$ oxides, which contributed to decreasing the $\operatorname{LogK}_{\mathrm{B}_{-}}$(int) constant values. $\log \mathrm{K}_{\mathrm{B}-}$ (int) was related to BMAC ( $\left.\mathrm{R}^{2}=0.86, p<0.05\right)$.

The average values for $\log \mathrm{K}_{-}$(int) and $\log \mathrm{K}_{+}$(int) for untreated and treated samples were similar. However, $\log \mathrm{K}_{+}$(int) was higher for the untreated samples and LogK_(int) was higher for the treated ones (Table 6).

Initial regression models for $\operatorname{LogK}_{\mathrm{B}-}$ (int), $\log \mathrm{K}_{+}$(int) or $\log \mathrm{K}_{-}$(int) were specified (Eq.15). In these models, the chemical and physical properties were natural log transformed, unlike the previous model (Eq.16).

Table 6 - Constant capacitance model surface complexation constants for the $\mathrm{SH}_{3} \mathrm{BO}_{4}{ }^{-}$complex formation LogK (int), protonation LogK+(int) and dissociation LogK-(int) reactions for the studied soils at different ionic strengths.

\begin{tabular}{|c|c|c|c|c|c|c|c|}
\hline \multirow{2}{*}{ Soils } & \multirow{2}{*}{$\begin{array}{c}\text { lonic } \\
\text { strength }\end{array}$} & \multicolumn{5}{|c|}{ Simultaneous optimization } & \multirow{2}{*}{$\mathrm{SOH}_{\mathrm{T}}$} \\
\hline & & $\operatorname{LogK}_{\mathrm{B}+}$ (int) & $\operatorname{LogK}_{\mathrm{B}-}$ (int) & LogK+(int) & LogK-(int) & Vy & \\
\hline & \multicolumn{7}{|c|}{ Untreated samples } \\
\hline \multirow{3}{*}{ Natric Palexeralf } & 0.05 & 0.779 & -7.877 & 8.977 & -11.564 & 6.308 & $2.475 \mathrm{E}-02$ \\
\hline & 0.10 & 1.308 & -7.738 & 9.030 & -11.666 & 25.796 & 2.014E-02 \\
\hline & 1.00 & 1.571 & -7.818 & 9.166 & -12.651 & 9.562 & $2.601 \mathrm{E}-02$ \\
\hline \multirow{3}{*}{ Aridic Paleustalf } & 0.05 & 1.269 & -7.610 & 7.870 & -11.499 & 27.749 & 1.895E-02 \\
\hline & 0.10 & 1.447 & -7.242 & 6.928 & -10.787 & 44.670 & $1.040 \mathrm{E}-02$ \\
\hline & 1.00 & 1.541 & -7.379 & 7.076 & -11.030 & 38.013 & $1.078 \mathrm{E}-02$ \\
\hline \multirow{3}{*}{ Xeric Torrifluvent } & $0.05^{*}$ & 1.285 & -7.097 & 7.453 & -10.409 & 23.970 & $2.739 \mathrm{E}-02$ \\
\hline & 0.10 & 1.674 & -7.134 & 8.290 & -10.528 & 4.344 & $1.806 \mathrm{E}-02$ \\
\hline & 1.00 & 1.855 & -7.332 & 8.450 & -11.019 & 19.119 & $2.181 \mathrm{E}-02$ \\
\hline \multirow{3}{*}{ Rhodic Eutroperox } & $0.05^{*}$ & 1.251 & -7.330 & 7.221 & -10.270 & 33.743 & $3.878 \mathrm{E}-02$ \\
\hline & 0.10 & 1.262 & -6.921 & 5.456 & -9.842 & 86.174 & $1.835 \mathrm{E}-02$ \\
\hline & $1.00^{*}$ & 1.642 & -7.112 & 6.988 & -10.598 & 46.677 & $2.270 \mathrm{E}-02$ \\
\hline \multirow{3}{*}{ Anionic Acroperox } & 0.05 & N.C. & N.C. & N.C. & N.C. & N.C. & $3.860 \mathrm{E}-02$ \\
\hline & 0.10 & 1.246 & -5.840 & 4.290 & -8.104 & 15.730 & 2.321E-02 \\
\hline & 1.00 & 1.564 & -5.395 & 4.819 & -8.041 & 37.658 & $1.952 \mathrm{E}-02$ \\
\hline \multirow[t]{3}{*}{ Average } & & 1.407 & -7.131 & 7.287 & -10.572 & 27.968 & $2.260 \mathrm{E}-02$ \\
\hline & \multicolumn{7}{|c|}{ Samples treated with sodium hypochlorite } \\
\hline & 0.05 & 0.511 & -8.272 & 9.065 & -11.004 & 20.679 & 2.507E-02 \\
\hline \multirow[t]{2}{*}{ Natric Palexeralf } & 0.10 & N.C. & N.C. & N.C. & N.C. & N.C. & 3.967E-02 \\
\hline & 1.00 & 1.421 & -8.006 & 8.660 & -12.011 & 10.077 & $1.514 \mathrm{E}-02$ \\
\hline \multirow{3}{*}{ Aridic Paleustalf } & 0.05 & 1.010 & -7.521 & 8.031 & -10.186 & 55.699 & $1.232 \mathrm{E}-02$ \\
\hline & 0.10 & 1.035 & -7.463 & 5.420 & -9.903 & 56.453 & 7.362E-03 \\
\hline & 1.00 & 1.413 & -6.901 & 7.087 & -9.466 & 42.182 & 7.460E-03 \\
\hline \multirow{3}{*}{ Xeric Torrifluvent } & $0.05^{*}$ & 1.195 & -7.238 & 6.141 & -9.823 & 66.663 & 2.730E-02 \\
\hline & 0.10 & 1.214 & -7.148 & 6.984 & -9.795 & 62.112 & $1.600 \mathrm{E}-02$ \\
\hline & 1.00 & 1.316 & -6.872 & 6.895 & -9.520 & 26.243 & $1.743 \mathrm{E}-02$ \\
\hline \multirow{3}{*}{ Rhodic Eutroperox } & $0.05^{*}$ & 1.130 & -6.410 & 4.870 & -8.740 & 70.750 & $2.470 \mathrm{E}-02$ \\
\hline & 0.10 & N.C. & N.C. & N.C. & N.C. & N.C. & 1.020E-02 \\
\hline & 1.00 & 1.460 & -7.010 & 6.190 & -9.760 & 64.860 & $6.710 \mathrm{E}-02$ \\
\hline \multirow{3}{*}{ Anionic Acroperox } & 0.05 & N.C. & N.C. & N.C. & N.C. & N.C. & 3.260E-02 \\
\hline & 0.10 & 1.690 & -6.590 & 4.920 & -9.600 & 28.830 & $1.750 \mathrm{E}-02$ \\
\hline & 1.00 & N.C. & N.C. & N.C. & N.C. & N.C. & 2.690E-02 \\
\hline Average & & 1.217 & -7.221 & 6.751 & -9.983 & 33.637 & $2.310 \mathrm{E}-02$ \\
\hline
\end{tabular}

All of the values of the complexation constants presented here were obtained simultaneously. ${ }^{*}$ This fit was obtained using the value [SOH]T from another ionic strength for the same sample. N.C = no convergence; $\mathrm{Vy}=$ global variance. 
Table 7 - Multiple linear regression models relative to complexation constants for the $\mathrm{SH}_{3} \mathrm{BO}_{4}^{-}$complex formation LogK (int), protonation LogK+(int) and dissociation constants LogK-(int).

\begin{tabular}{|c|c|c|}
\hline Multiple linear regression model & $\mathrm{R}^{2}$ & Prob. $>\mathrm{F}^{*}$ \\
\hline \multicolumn{3}{|c|}{ All samples } \\
\hline $\operatorname{LogK}_{B-}=-3.180+2.130 \ln (S S A)-0.165 \ln (I C)$ & 0.79 & 0.0001 \\
\hline $\operatorname{LogK}+=10.430-0.632 \ln (\mathrm{CEC})+0.363 \ln (\mathrm{OC})+0.203 \ln (\mathrm{IC})-1.433 \ln (\mathrm{AlC})$ & 0.83 & 0.0001 \\
\hline LogK- $=-13.790+0.707 \ln ($ CEC $)-0.377 \ln (\mathrm{OC})-0.150 \ln (\mathrm{IC})+1.232 \ln (\mathrm{AlC})$ & 0.85 & 0.0001 \\
\hline \multicolumn{3}{|c|}{ Untreated samples } \\
\hline $\operatorname{LogK}_{B-}=-5.772-0.3771 \ln (\mathrm{OC})+1.116 \ln (\mathrm{AlC})$ & 0.86 & 0.0001 \\
\hline $\operatorname{LogK}+=0.825-3.880 \ln (S S A)+0.408 \ln (I C)$ & 0.87 & 0.0001 \\
\hline LogK- $=-6.653-0.284 \ln (\mathrm{CEC})-0.680 \ln (\mathrm{OC})+2.037 \ln \left(\mathrm{Al}_{c}\right)$ & 0.91 & 0.0001 \\
\hline \multicolumn{3}{|c|}{ Samples treated with sodium hypochlorite } \\
\hline $\operatorname{LogK}_{B}=-7.0664-0.3723 \ln (\mathrm{OC})-0.0289 \ln (\mathrm{IC})+0.9158 \ln \left(\mathrm{Al}_{\mathrm{C}}\right)$ & 0.83 & 0.0042 \\
\hline $\operatorname{LogK}+=8.122-1.014 \ln \left(\mathrm{Fe}_{c}\right)$ & 0.37 & 0.0475 \\
\hline LogK- $=-9.883-0.707 \ln (\mathrm{OC})-0.049(\mathrm{IC})+1.168\left(\mathrm{Al}_{c}\right)$ & 0.82 & 0.0055 \\
\hline
\end{tabular}

${ }^{*}$ Significant at $p<0.15$.

$\mathrm{yi}=\mathrm{b}_{(0, \mathrm{i})}+\mathrm{b}_{(1, \mathrm{i})} \ln (\mathrm{CEC})+\mathrm{b}_{(2, \mathrm{i})} \ln (\mathrm{SSA})+\mathrm{b}_{(3, \mathrm{j}, \mathrm{i}} \ln (\mathrm{OC})+\mathrm{b}_{(4, \mathrm{i})} \ln (\mathrm{IC})+\mathrm{b}_{[(5, \mathrm{i})} \ln \left(\mathrm{Fe}_{\mathrm{c}}\right)+$

$$
\mathrm{b}_{(6, \mathrm{i})} \ln \left(\mathrm{Al}_{\mathrm{c}}\right)
$$

where $y$ represents $\operatorname{LogK}_{\mathrm{B}_{-}}$(int), $\log _{+}$(int) or $\log \mathrm{K}_{-}($int $)$; $\mathrm{b}_{0}$ through $\mathrm{b}_{6 \mathrm{i}}$ the empirical regression coefficients, and $\varepsilon$ the statistic random error component.

Although $\mathrm{Al}$ is the most important chemical attribute in determining the models for $\operatorname{LogK}_{B}$ (int) for the treated and untreated samples it was not sufficiently significant to be included in the regression model when all samples were evaluated despite presenting a high correlation coefficient when related to $\log \mathrm{K}_{\mathrm{B}}$ (int) $(\mathrm{r}=$ $0.83, p<0.05)$. The statistical analysis applying to these equations is provided in Table 7 .

For all conditions where $\log \mathrm{K}_{\mathrm{B}-}$ (int) was predicted, the untreated samples had higher correlation coefficients and organic matter removal did not improve the Vy values, as expected.

\section{Acknowledgments}

We thank the Fundação Araucária (PRONEX: Protocol no 24732/2012), Conselho Nacional de Desenvolvimento Científico e Tecnológico - CNPq (Projects $\mathrm{n}^{\circ}$ 312033/2013-3 e 485221/2012-8) and Coordenação de Aperfeiçoamento de Pessoal de Nível Superior - CAPES (Brazil) for financial support for this research. We also thank Pangki Xiong, from the Salinity Laboratory, CA, USA, and Ivan Granemann de Souza Junior from Universidade Estadual de Maringá, PR, BR, for technical assistance.

\section{Authors' Contributions}

Conceptualization: Costa, A.C.S.; Santos, P.; Goldberg, S. Data acquisition: Santos, P. Data analysis: Costa , A.C.S.; Santos, P.; Goldberg, S. Design of Methodology: Costa, A.C.S.; Santos, P.; Goldberg, S. Software development: No software was developed. Writing and editing: Costa, A.C.S.; Santos, P.; Goldberg, S.

\section{References}

Alleoni, L.R.F.; Camargo, O.A. 2000. Boron adsorption in soils from the state of São Paulo, Brazil. Pesquisa Agropecuária Brasileira 35: 413-421.

Anderson, J.V. 1963. An improved pretreatment for mineralogical analysis of samples containing organic matter. Clays and Clay Minerals 10: 380-388.

Bingham, F.T.; Page, A.L.; Coleman, N.T.; Flach, K. 1971. Boron adsorption characteristics of selected amorphous soils from Mexico and Hawaii. Soil Science Society of America Proceedings 35: 546-550.

Bohinc, K.; Kralj-Iglič,V.; Iglič, A. 2001. Thickness of electrical double layer: effect of ion size. Electrochimica Acta 46: 3033-3040.

Cakmak, I.; Romheld, V. 1997. Boron deficiency-induced impairments of cellular functions in plants. Plant and Soil 193: 71-83.

Cihacek, J.L.; Bremner, J.M. 1979. A simplified ethylene-glycolmono-ethyl procedure for assessment of soil surface area. Soil Science Society of America Journal 43: 821-822.

Coffin, D.E. 1963. A method for the determination of free iron in soils and clays. Canadian Journal of Soil Science 43: 9-17.

Costa, A.C.S.; Bigham, J.M. 2009. Iron oxides = Óxidos de ferro. p. 505-572. In: Melo, V.F.; Alleoni, L.R.F., eds. Chemistry and mineralogy of soils: Basic concepts. = Química e mineralogia dos solos: Conceitos básicos. Sociedade Brasileira de Ciência do Solo, Viçosa, MG, Brazil (in Portuguese).

Goldberg, S.; Glaubig, R.A. 1986. Boron adsorption on California soils. Soil Science Society of America Journal 50: 1173-1176.

Goldberg, S. 1991. Sensitivity of surface complexation modeling to the surface site density parameter. Journal of Colloid and Interface Science 145: 1-9.

Goldberg, S.; Forster, H.S. 1991. Boron adsorption on calcareous soils and reference calcites. Soil Science 152: 304-310.

Goldberg, S.; Forster, H.S.; Heick, E.L. 1993. Boron adsorption mechanisms on oxides, clay minerals, and soils inferred from ionic strength effects. Soil Science Society of America Journal 57: 704-708.

Goldberg, S. 1997. Reactions of boron with soils. Plant and Soil 193: $35-48$. 
Goldberg, S. 1999. Reanalysis of boron adsorption on soils and soil minerals using the constant capacitance model. Soil Science Society of America Journal 63: 823-829.

Goldberg, S.; Lesch, S.M.; Suarez, D.L. 2000. Predicting boron adsorption by soils using soil chemical parameters in the constant capacitance model. Soil Science Society of America Journal 64: 1356-1363.

Goldberg, S. 2004. Modeling boron adsorption isotherms and envelopes using the constant capacitance model. Vadose Zone Journal 3: 676-680.

Goldberg, S. 2005. Equations and models describing adsorption processes in soils. p. 489-517. In: Tabatabai, M.A.; Sparks, D.L., eds. Chemical Processes in Soils. American Society of Agronomy, Madison, WI, USA.

Goldberg, S.; Su, C. 2007. New advances in boron soil chemistry. p. 313-330. In Xu, F., ed. Advances in plant and animal boron nutrition. Springer, Dordrecht, Netherlands.

Goldberg, S.; Suarez, D.L. 2012. Role of organic matter on boron adsorption-desorption hysteresis of soils. Soil Science 177: 417423.

Gupta, U.C.; Jame, Y.W.; Campbell, C.A.; Leyshon, A.J.; Nicholaichuk, W. 1985. Boron toxicity and deficiency: a review. Canadian Journal of Soil Science 65: 381-409.

$\mathrm{Gu}$, B.; Lowe, L.E. 1990. Studies on the adsorption of boron on humic acids. Canadian Journal of Soil Science 70: 305-311.

Herbelin, A.; Westall, J. 1999. FITEQL 4.0: A computer program for determination of chemical equilibrium constants from experimental data. Oregon State University, Department of Chemistry, Corvalis, OR, USA.

Keren, R.; Bingham, F.T. 1985. Boron in water, soils, and plants. Advanced Soil Science 1: 229-276.

Lemarchand, E.; Schott, J.; Gaillardet, J. 2005. Boron isotopic fractionation related to boron sorption on humic acid and the structure of surface complexes formed. Geochimica et Cosmochimica Acta 69: 3519-3533.

Marzadori, C.; Antisari, L.V.; Ciavatta, C.; Sequi, P. 1991. Soil organic matter influence on adsorption and desorption of boron. Soil Science Society of America Journal 55: 1582-1585.

Mehra, O.P.; Jackson, M.L. 1960. Iron oxide removal from soils and clays by a dithionite-citrate system buffered with sodium bicarbonate. Clays and Clay Minerals 7: 317-327.

Moore, D.M.; Reynolds, R.C. 1997. X-ray diffraction and the identification and analysis of clay minerals. 2ed. Oxford University Press, New York, NY, USA.

Olson, R.V.; Berger, K.C. 1947. Boron fixation as influenced by $\mathrm{pH}$, organic matter content and other factors. Soil Science Society of America Journal 11: 216-220.
Rhoades, J.D. 1982. Cation exchange capacity. p.149-157. In: Page, A.L.; Miller, R.H.; Keeney, D.R., eds. Methods of soil analysis. Part 2. Chemical and microbiological properties. 2ed. American Society of Agronomy, Madison, WI, USA.

Santos, H.G.; Jacomine, P.K.T; Anjos, L.H.C.; Oliveira, V.A.; Lumbreras, J.F.; Coelho, M.R.; Almeida, J.A.; Araujo Filho, J.C.; Oliveira, J.B.; Cunha, T.J.F. 2018. Brazilian soil classification system. 5ed. Embrapa Solos, Rio de Janeiro, RJ, Brazil.

Sarkar, D.; De, D.K; Das, R.; Mandal, B. 2014. Removal of organic matter and oxides of iron and manganese from soil influences boron adsorption in soil. Geoderma 214: 213-216.

Sharma, K.R.; Srivastava, P.C.; Srivastava, P.; Singh, P.V. 2006. Effect of farmyard manure application on adsorptiondesorption characteristics of some soils. Chemosphere 65: 769777 .

Sims, J.R.; Bingham, F.T. 1968. Retention of boron by layer silicates, sesquioxides and soil materials. II. Sesquioxides. Soil Science Society of America Journal 32: 364-369.

Soares, M.R.; Casagrande, J.C.; Alleoni, L.R.F. 2008. Boron adsorption in acric soils as a function of $\mathrm{pH}$ variation = Adsorção de boro em solos ácricos em função da variação do pH. Revista Brasileira de Ciência do Solo 32: 111-120 (in Portuguese).

Soil Survey Staff. 2014. Keys to soil taxonomy. 12ed. USDA-NRCS, Washington, DC, USA.

Sposito, G. 2008. The chemistry of soils. 2ed. Oxford University Press, New York, NY, USA.

Su, C.; Suarez, D.L. 1995. Coordination of adsorbed boron: a FTIR spectroscopic study. Environmental Science and Technology 29: 302-311.

Yermiyaho, U.; Keren, R.; Chen, Y. 1995. Boron sorption by soil in the presence of composted organic matter. Soil Science Society of America Journal 59: 405-409.

Zimmermann, M.; Leifeld, J.; Abiven, S.; Schmidt, M.W.I.; Fuhrer, J. 2007. Sodium hypochlorite separates an older soil organic matter fraction than acid hydrolysis. Geoderma 139: 171-179.

Westall, J.; Hohl, H. 1980. A comparison of electrostatic models for the oxide/solution interface. Advances in Colloid and Interface Science 12: 265-294.

Whittig, L.D; Allardice, W.R. 1986. X-rays diffraction techniques. p. 331-362. In: Klute, A., ed. Methods of soil analysis: physical and mineralogical methods. American Society of Agronomy, Madison, WI, USA. 